\title{
NGOYOG BALI JINJIT
}

\section{Oleh: Jiyu Wijayanti}

Jurusan Tari, Fakultas Seni Pertunjukan, Institut Seni Indonesia Yogyakarta Alamat Email: jiyulucia@gmail.com

\section{RINGKASAN}

Ngoyog bali Jinjit, adalah judul dari koreografi yang dirancang, ditarikan oleh empat penari putri. Istilah ngoyog bali jinjit didapat dalam teknik gerak dalam tari gaya Yogyakarta yang selanjutnya dijadikan rangsang kinestetis, disajikan secara simbolik representasional dengan tipe tari studi dan murni.

Metode yang dipakai dalam penciptaan tari ini adalah metode kontruksi oleh Jacqueline Smith. Hal ini dipandang sesuai diterapkan dalam membimbing mahasiswa pemula untuk mewujudkan suatu koreografi. Tahapan-tahapan yang sifatnya hirarkis, yang satu mengkait dengan yang lain, yang dimulai dari adanya rangsang, kemudian ditanggapi dengan memperhatikan langkah-langkah dan tahapan akhirnya mampu membentuk rangkaian motif yang selanjutnya dirangkai dalam sebuah kesatuan yang disebut dengan koreografi.

Ngoyog Bali Jinjit dipahami sebagai gerak yang terus menerus, dari titik kembali ke titik, memberi kesan ada suatu proses perputaran. Unsur-unsur putaran tangan, kaki, dan badan diujudkan dalam motif-motif gerak yang terangkai. Permainan ruang dan waktu mengacu pada metode konstruksi tiga yaitu motif menuju komposisi kelompok, dengan memvariasikan antara gerak rampak dan berturutan.

Kata Kunci: Ngoyog bali jinjit, metode kontruksi, koreografi

\section{ABSTRACT}

Ngoyog bali Jinjit, is a title of choreography designed, danced by four female dancers. The term ngoyog bali jinjit is direved from the movement techniques in Yogyakarta style dance, which is later used as kinesthetic stimuli, presented symbolical representationally using the study and pure tipes of dance movement.

The method used in the creation of this dance is invented by Jacqueline Smith. It is considered appropriate to be applied in guiding novice students to create a choreography. Hierarchical stages 
are relate to the others, which starts from the stimulus, then responded by the next steps. Finally, the form a series of movement become an assembled union called the choreography.

Ngoyog Bali Jinjit is understood as a continuous movement,from one point and return to this point, giving the impression that there is a process of rotation. Elements of hands, feet, and body rotation are embodied in movement that are created together. The usage of space and time refers to the third construction method by Smith, i. e. the movement to form a group composition, by varying the unison and sequence it.

Keyword: Ngoyog Bali jinjit, contraction method, choreography

\section{PENDAHULUAN}

Maraknya dunia seni tari semakin menampakkan keberagamannya, berbagai pertunjukan tari digelar dengan berbagai tajuk, dari yang bersifat klasik, kreasi baru, kontemporer, sampai pada seni instalasi ataupun post modern. Hal ini tidak mengherankan karena banyak bermunculan seniman-seniman muda yang berlatar belakang autodidak maupun yang menekuni tari secara formal, seperti yang ada di Institut seni Indonesia Yogyakarta. Kemunculan seniman (koreografer) ini mampu memenuhi kebutuhan berbagai kegiatan yang digelar seperti lomba, festival, ritual sampai pada seni tontonan ataupun hiburan.

Institut Seni Indonesia Yogyakarta, Fakultas Seni Pertunjukan, khususnya Program Studi Seni Tari menyelenggarakan pendidikan yang menghasilkan para lulusannya menjadi seorang koreografer maupun peneliti tari. Dari tahun ke tahun lulusan yang mengambil jalur penciptaan semakin banyak jumlahnya dan menunjukkan kualitas yang lebih baik, hal ini salah satunya karena ditunjang oleh kurikulum yang memadai. Salah satu penunjang jalur penciptaan, yaitu mata kuliah Koreografi. Kurikulum yang dibangun, dimulai dari dasar koreografi 1 dan 2, dilanjutkan koreografi yang dibagi dalam 3tahap, yaitu koreografi 1, 2, dan 3. Setelah melewati tahapan ini baru sampai pada karya Tugas akhir yang berupa sebuah garapan koreografi. Kiranya tahapan dan pengalaman ini mampu menjadi bekal untuk mengarungi dunia koreografi yang tak terbatas.

Pengalaman mengajar dalam mata kuliah dasar koreografi, sering ditemui beberapa mahasiswa kesulitan untuk memulai, sehingga perlu dicarikan solusi akan permasalahan ini. Biasanya mereka takut untuk memulai karena merasa tidak memiliki teknik yang baik, ada pula yang merasa takut 
salah, beberapa diantaranya bertanya dari mana harus memulai. Pertanyaan ini seharusnya tidak terjadi jika mereka menyadari bahwa substansi koreografi adalah gerak, sedangkan gerak adalah hal yang paling elementer dari sebuah kehidupan. Berkait dengan hal ini, perancangan koreografi dilakukan dengan mencoba menerapkan metode konstruksi yang ditawarkan oleh Jacqueline smith dalam bukunya Dance Composition a practical guide for teachers yang telah diterjemahkan oleh Ben Suharto dengan judul Komposisi Tari Sebuah Petunjuk Praktis Bagi Guru, tahapan- tahapan yang ditawarkan dalam metode ini sangat menuntun, terutama bagi pemula.

Istilah koreografi, menurut Sumandiyo Hadi populer di Indonesia sejak munculnya tari kreasi baru, yang dipelopori oleh Bagong Kusudihardjo dan Wisnoe Wardhana di Yogyakarta sedangkan di Bali dipelopori oleh I Mario dan I Nyoman Kaler(Hadi ,2011: 6). Sebagai suatu konsep, koreografi yang dipahami sebagai penataan tari, adalah suatu proses perencanaan, penyeleksian, sampai pada pembentukan. Proses ini melalui langkah yang dilakukan dengan berbagai tahapan. Tahapan-tahapan tersebut dapat dilakukan dengan berbagai cara tergantung si pencipta atau koreografernya, namun pada umumnya selalu berawal dari sebuah konsep yang dituangkan dalam berbagai metode terpilih, yang akhirnya membentuk sesuatu yang bisa diidentifikasi kebentukannya, yang selanjutnya bisa dipertunjukkan di hadapan penonton.

Kesadaran, ketekunan, dan kecermatan memahami teori ini, akan ditemukan cara yang simpel untuk membuat koreografi, memang ini pandangan yang sangat subyektif sifatnya, sehingga perlu diuji ketepatan ataupun kebenarannya. Hasil dari perancangan atau penciptaan ini diharapkan bisa menjadi model acuan atau prototipe bagi para pemula untuk berani tampil (menunjukkan dirinya) sebagai seorang koreografer. Penciptaan koreografi ini berbentuk koreografi kelompok, ditarikan oleh empat penari putri, dan diberi judul Ngoyog Bali jinjit.

Ngoyog bali Jinjit adalah salah satu teknik gerak dalam pembelajaran tari gaya Yogyakarta, khususnya tari putra alus, dalam penciptaan ini akan dijadikan sumber acuan dalam pencarian gerak. Ngoyog bali jinjit adalah suatu rangkaian gerak yang terus menerus secara kontinyu, secara visual terlihat dari titik kembali ke titik, terkesan seperti ada garis yang berkesinambungan, ruang yang tercipta seperti lingkaran. Gerak yang terus menerus dan berkesinambungan ini dalam dunia tari dikenal dengan gerak mbanyu mili.

Kesan adanya garis imajiner lingkaran ( putaran) dimaknai sebagai perjalanan hidup, mengikuti roda kehidupan yang selalu bergulir dari waktu ke waktu sampai entah kapan akan 
terhenti. Koreografi ini akan dipentaskan di proscenium stage yang memiliki satu arah pandang penonton, ruang atau sudut-sudut yang ada akan dimanfaatkan untuk penonjolan titik/pusat perhatian.

\section{PEMBAHASAN}

Proses pembentukan suatu koreogrfi melalui beberapa tahapan. Secara umum tahapan tersebut dikenal dengan eksplorasi, improvisasi, pembentukan(forming), hal yang tidak kalah penting diperlukan evaluasi dalam setiap pentahapannya. Tahapan-tahapan tersebut tidaklah harus secara hirarkis pelaksanaannya, namun bisa saling dipertukarkan kedudukannya

Eksplorasi dapat diartikan penjajagan, hal ini termasuk berpikir, berkhayal, sampai pada tindakan mengeksplorasi tubuh. Eksplorasi lebih mengedepankan pencarian berdasarkan kedalaman, perluasan, kemungkinan, dari sumber yang diacu. Improvisasi dapat ditengarai dengan adanya spontanitas, mencoba dan mencoba, hal ini bisa berdasar memori yang ada dalam diri maupun gerak spontan yang muncul. Antara eksplorasi dan improvisasi saling memberikan stimulus dan respon sehingga penemuanpenemuan gerak bisa saling melengkapi seturut logika gerak. Komposisi merupakan hasil final yang telah disusun dan telah melalui evaluasi. Secara konseptual koreografi merupakan proses penyeleksian, atau pembentukan gerak menjadi wujud tarian (Sumandiyo Hadi 2003:60).

Langkah atau metode di atas, tentu saja berorientasi pada konsep dasar pemikiran yaitu mencipta koreografi berdasar metode kontruksi yang ditawarkan oleh Jacqueline Smith. Berdasarkan metode ini, suatu koreografi bisa terwujud melalui beberapa tahapan, masing-masing tahapan memunculkan hasil yang harus dikembangkan pada tahapan berikutnya, sehingga nantinya akan menjadi kesatuan yang utuh. Metode ini terdiri dari Metode Konstruksi 1 sampai 5, masing-masing merupakan tata hubungan yang hirarki sifatnya, yang susul menyusul, kait mengkait. Masing-masing tahapan ini selalu memanfaatkan eksplorasi, improvisasi dan komposisi dalam pentahapannya.

Metode Konstruksi 1 membahas tentang awal komposisi, berawal dari adanya rangsang sampai terbentuknya motif.

Metode Konstruksi 2 : merupakan pengembangan motif, penerapan dari metode ini yaitu setelah ditentukan motif awal, maka dilakukan berbagai improvisasi dengan memanfaatkan ruang, waktu, dan tenaga, untuk mendapatkan berbagai variasi. Repetisi dan pengembangan aksi menuntun dalam berimprovisasi.

Metode Konstruksi 3, merupakan perangkaian motif menuju komposisi 
kelompok. Gerak, ruang dan waktu merupakan tiga elemen yang tidak terpisahkan. Dalam koreografi kelompok secara garis besar waktu dibedakan menjadi dua yaitu rampak dan selang seling, sedangkan unsur ruang meliputi disain-disain yang ditimbulkan oleh gerak yang dilakukan.

Metode Konstruksi 4. Bentuk tari. Merupakan langkah perangkaian dari motifmotif yang telah ditemukan. Dicermati kembali atas frase gerak, seksi(bagian) sampai pada bentuk atau struktur secara keseluruhan.

Metode Konstruksi 5, merupakan tahap evaluasi dengan memperhatikan variasi, pengulangan, kontras, transisi, proporsi dan keseimbangan, kesatuan.

Penjelasan di atas dapat digambarkan dalam bagan alir seperti ini:

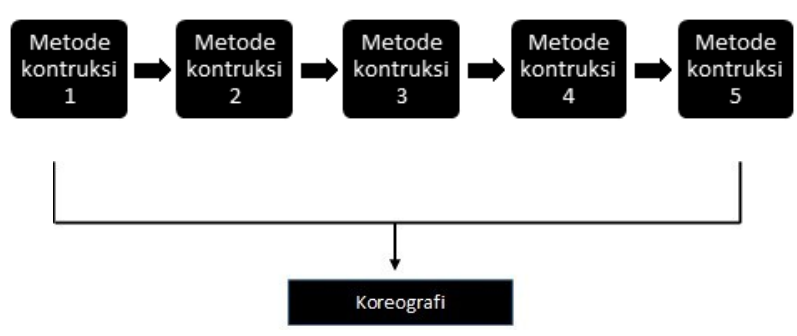

A. Konsep Penciptaan

Koreografi yang dipahami sebagai tataan gerak kehadirannya dituntut untuk memberikan sesuatu pada khalayak penontonnya. Di sisi yang lain konsep pembentukannya dilalui dengan menerapkan sebuah metode sebagai landasannya. Seperti apa yang telah dijelaskan di depan, koreografi ini terbentuk melalui tahapan-tahapan dalam metode Konstruksi yang disampaikan Jacqueline Smith.

Penerapan metode di atas, akhirnya menghasilkan suatu kerangka pikir sebagai berikut:

1. Tema Tari

Koreografi ini bertema non literer tidak mengisahkan sesuatu yang khusus, namun demikian apabila ada rangkaian gerak yang menimbulkan kesan tertentu/sesuatu, ini merupakan hasil pencarian murni dari logika gerak yang dilakukan.

2. Judul Tari

Ngoyog Bali Jinjit dipilih untuk judul koreografi ini, hal ini dikarenakan rangsang awal adalah kinestetis dari tehnik tari gaya yogyakarta khususnya putra alus yang dijadikan sumber eksplorasi dan improvisasi yang dilakukan. Kesan keruangan dari titik kembali ke titik dari motif gerak ini dijadikan sumber inspirasi dalam mengolah koreografi ini.

Sinopsis: "Koreografi ini tercipta melalui metode Kontruksi, dengan mengedepankan rangsang kinestetis yang dikemas dalam tipe tari studi. Pergeseran, perputaran, perbedaan layaknya suatu perjalanan, dari titik kembali ke titik dimaknai sebagai rotasi kehidupan...Ngoyog Bali Jinjit “ 


\section{Jumlah Penari.}

Secara khusus jumlah penari tidak menjadi permasalahan utama, namun jumlah empat ini dipandang mampu untuk mewujudkan koreografi kelompok beserta aspek-aspek yang melingkupinya. Aspek yang dimaksud seperti unity, repetition, variation, transition. Keempat penari terpilih ini merupakan mahasiswa yang pernah mengikuti mata kuliah Dasar Koreografi, sehingga mereka mampu menterjemahkan apa yang menjadi kehendak koreografer.

Keempat penari ini tidak hanya sebagai media ekspresi, namun juga berpartisipasi aktif di dalam mewujudkan koreografi ini.

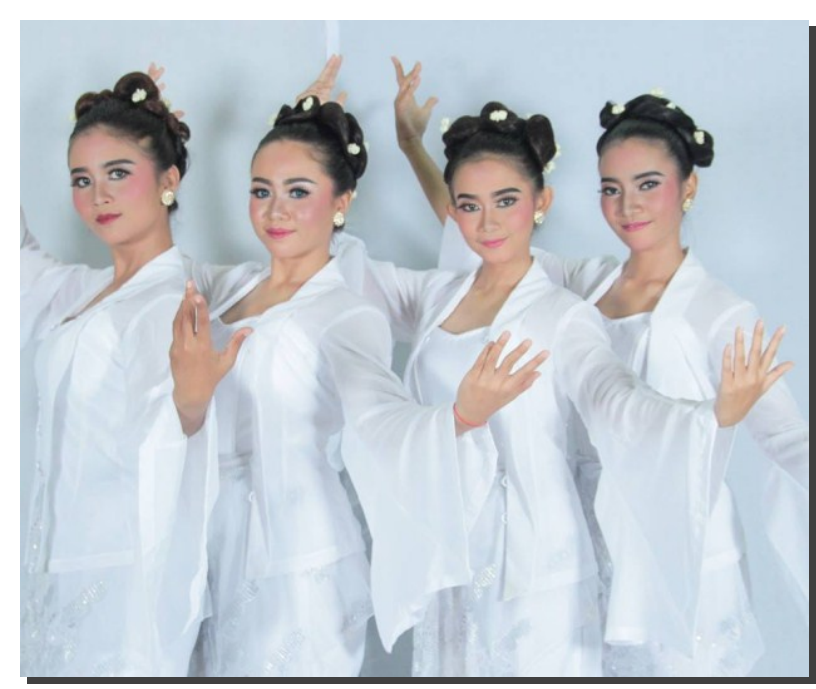

Gamb.1 Empat penari (Foto A'ari Kusuma)

\section{Gerak}

Ngoyog bali jinjit menjadi sumber utama pencarian gerak yang dilakukan. Mencermati sumber gerak yang sangat sederhana yang berupa gerakan kaki, maka dicoba dilakukan pada bagian tubuh yang lain, sehingga memunculkan gerak ayunan tangan dan badan.
Kesan adanya aspek putaran dalam ngoyog bali jinjit menuntun eksplorasi dan improvisasi yang dilakukan. Gerak-gerak yang tercipta merupakan hasil pengembangan gerak, ruang dan waktu .

Unsur-unsur yang ada dalam ngoyog bali jinjit dicoba dalam improvisasi dan eksplorasi yang dilakukan. Dari unsur ngoyog dihasilkan ngoyog junjung, ngoyog srimpet, ngoyog junjung tekuk, ngoyog nranjal. Pengembangan dari jinjit menghasilkan encot, juga ayunan kaki. Sebagai contoh gerak putaran tangan, dilakukan dengan poros pada bahu, siku, dan juga putaran pergelangan tangan. Permainan tempo dari cepat ke lambat atau sebaliknya memunculkan ritme yang ajeg dan tidak ajeg.

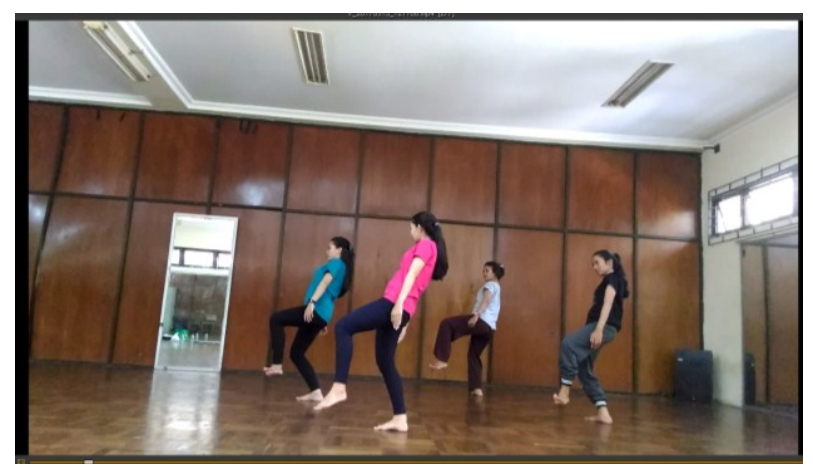

Gamb.2 sikap junjung tekuk nglayang (foto :Jiyu)

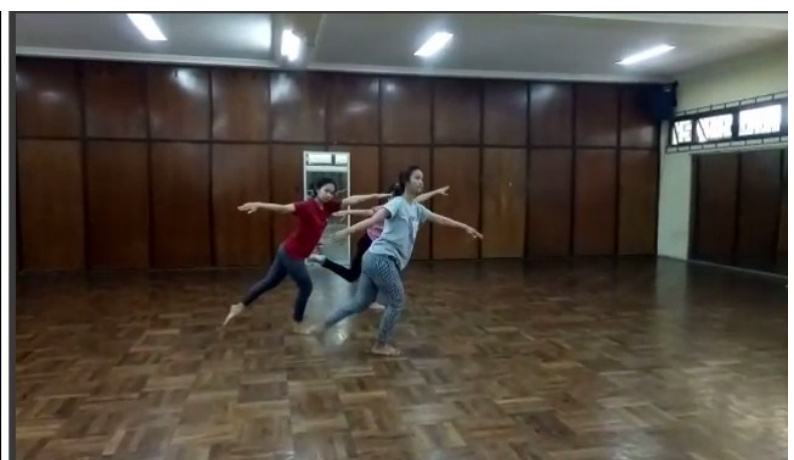

Gamb.3. Sikap rentang tangan junjung mayuk ( Foto rinjani) 


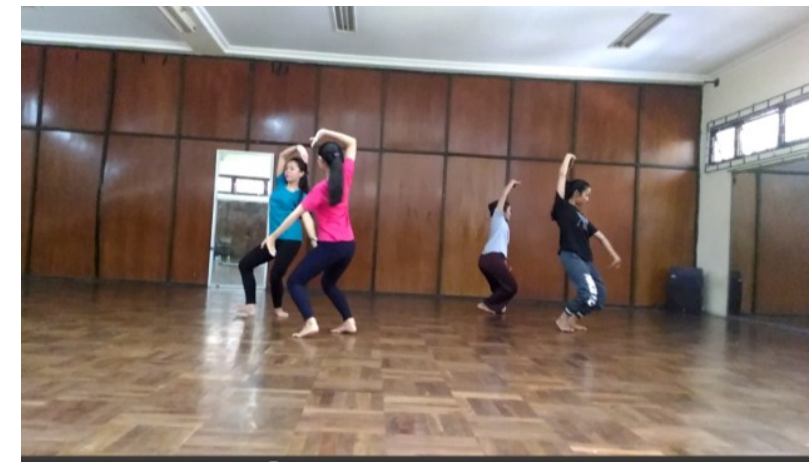

Gamb.4. Sikap putaran badan dan tangan (Foto: Jiyu)

\section{Musik}

Koreografi ini diiringi oleh seperangkat ensembel musik yang merupakan perpaduan antara musik diatonis dan pentatonis. Beberapa instrumen musik yang dipergunakan diantaranya chime, bass elektrik, saxsophon, floor drum, keybord, biola, gentha, symbal, rebana, thok-thok, kemanak, kendang, dan gender. Komposisi yang tercipta sifatnya memperkuat suasana dengan memberi ketukan/ beat pada gerak dan juga bersifat ilustratif .

\section{Tempat Pentas}

Proscenium stage dipilih sebagai tempat pertunjukan, hal ini dengan pertimbangan adanya setting yang akan digunakan. Selain itu komposisi atau pola gerak beserta pola lantai yang dibuat, sangat menguntungkan apabila dilihat dari satu arah pandang penonton.

\section{Setting}

Setting berupa kain putih panjang berploi, yang menjuntai dari atas para-para, berada di dead centre, pada adegan akhir kain ini direspon oleh penari. Selain memberi keindahan, setting ini dimaknai sebagai awal dan akhir suatu perputaran, perjalanan, dan perbedaan.

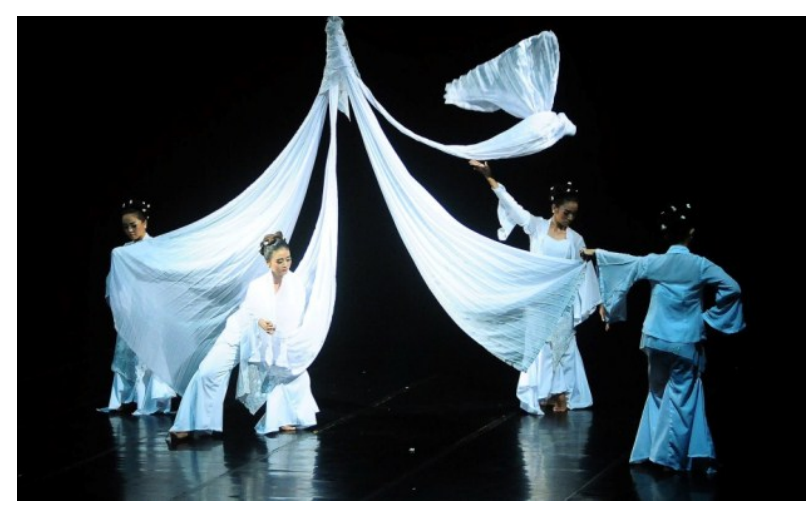

Gamb.5. setting dan penari ( Foto: Pakjo)

\section{Tata Rias dan Busana}

Pada dasarnya rias yang dikenakan hanya bersifat korektif, dengan mempertebal garisgaris wajah. Tataan rambut berupa sanggul, dengan disain sederhana yang dihiasi bunga melati sebagai kesatuannya.

Disain busana berupa celana panjang dan baju atasan dilengkapi dengan kamisol dan kain tille, warna yang dipilih adalah putih. Jenis kain yang bertekstur halus dan ringan dipilih untuk mewujudkan busana tari, seperti gambar di bawah ini.

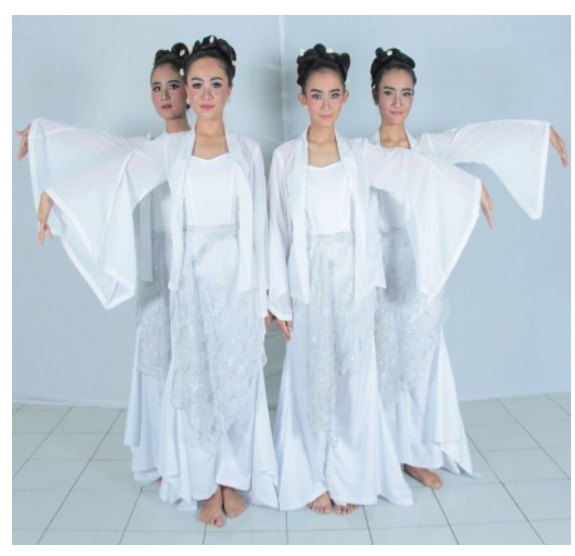

Gamb.6. Rias dan busana penari (Foto: A'ari Kusuma) 
Warna putih dipilih, karena dianggap netral tidak menunjukkan karakter tertentu namun warna putih memberi kesan bersih dan terlihat kontras dengan back drop yang menjadi latar belakangnya. Disain yang lebar dan longgar akan memunculkan disain tertunda atas gerak yang dilakukan penari.

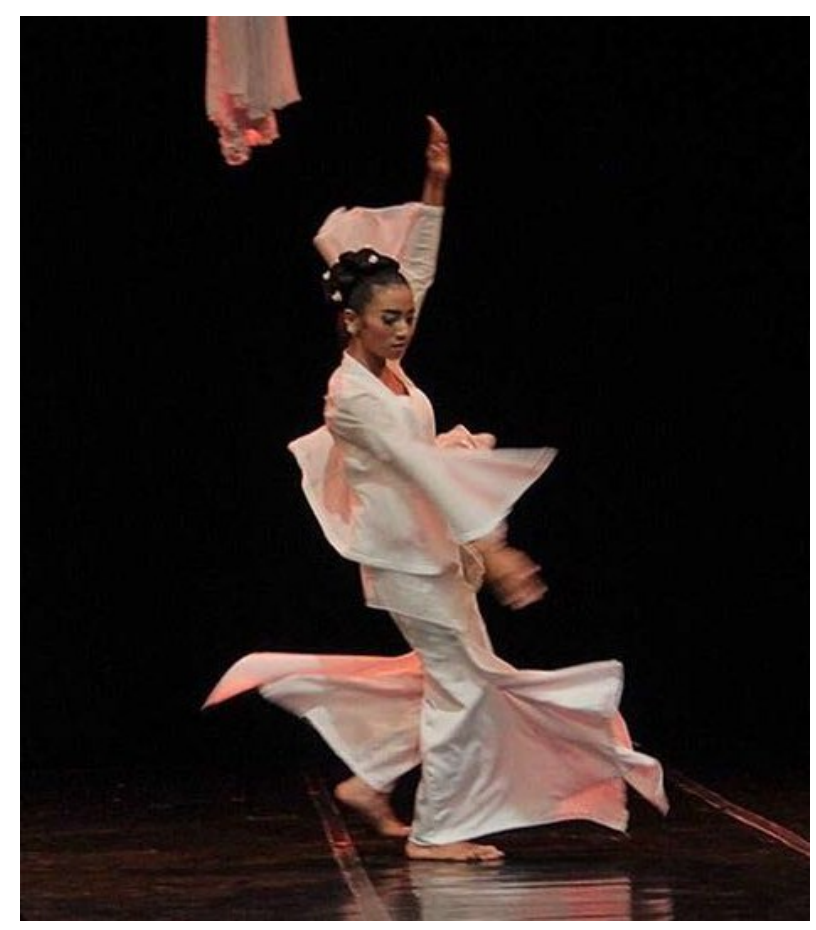

Gamb.7. Disain tertunda efek motif baling (Foto A'ari Kusuma)

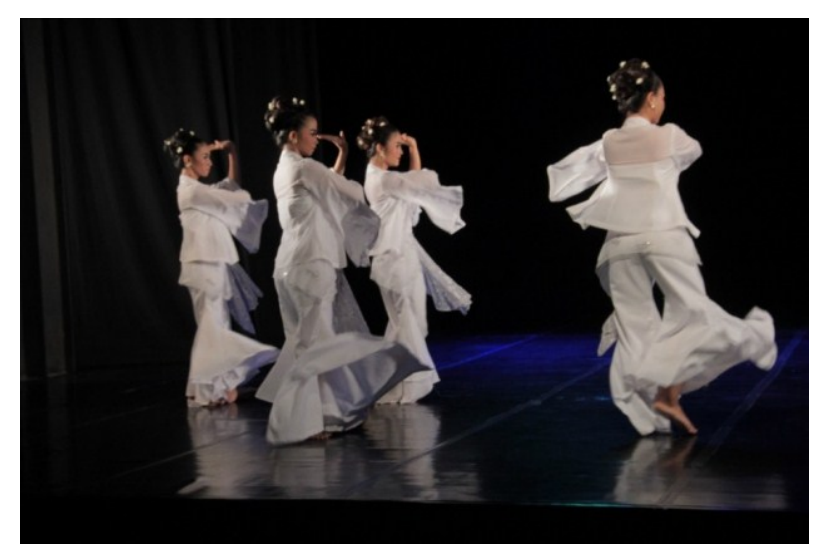

Gamb.8. Disain tertunda efek motif atur-atur (Foto A'ari Kusuma)

\section{B. Proses Penciptaan}

\section{Metode kontruksi 1.}

Rangsang dipahami sebagai sesuatu yang membangkitkan fikir, menurut Smith rangsang bisa didapat melalui auditif, peraba, visual, idea, kinestetis,( Suharto: 1985:20). Hal ini rangsang kinestetis yang berupa gerak ngoyog bali jinjit menjadi satu-satunya rangsang awal. Gerak ini terdapat dalam tari gaya Yogyakarta dalam karakter putra halus. Secara visual, terlihat sangat sederhana, diawali posisi tanjak kiri, bergerak ngoyog kiri, kembali ke posisi tanjak kiri, atau sebaliknya, diawali tanjak kanan, ngoyog kanan, kembali tanjak kanan. Ngoyog adalah proses memindahkan berat badan dari satu sisi ke sisi yang lainnya, sedangkan tanjak adalah posisi awal dalam suatu gerakan.. Ngoyog bali jinjit didominasi oleh gerak kaki. Durasi gerak ini hanya 2 hitungan.

Tipe Tari yang dipilih adalah studi dan murni. Tipe tari studi ditandai dengan teba gerak yang terbatas, hal ini dimaksudkan untuk mencoba bereksplorasi degan berbagai kemungkinan yang bersumber pada gerak yang sangat singkat dan sederhana yaitu ngoyog bali jinjit. Kesan putaran dari ngoyog bali jinjit ini, dicoba dilakukan pada anggota tubuh yang lain seperti tangan maupun badan. Dari proses 


\section{JOGED}

ISSN: $1858-3989$

ini akhirnya menghasilkan gerak murni yang hanya memandang gerak itu sendiri.

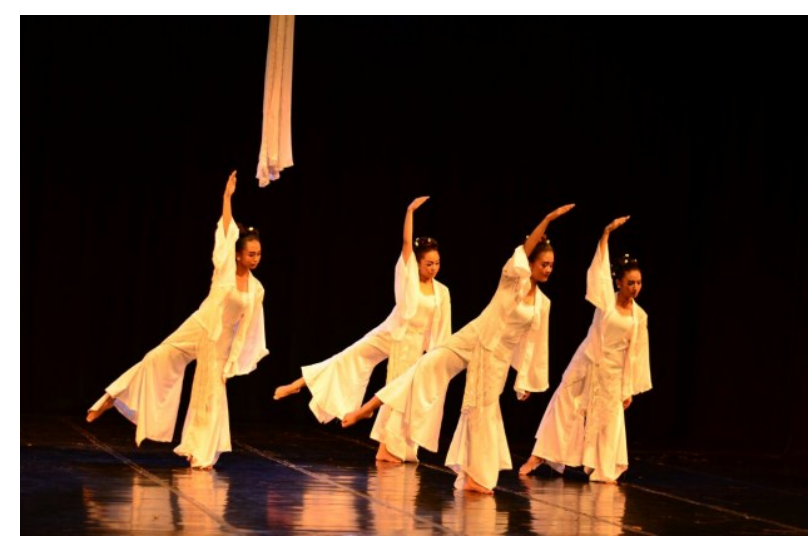

Gamb. 9. Sikap putaran tangan dan rentang kaki (Foto: daniel)

Mode penyajian koreografi ini cenderung simbolis representatif. Gerak-gerak yang hadir merupakan upaya pencarian dengan mengedepankan pengembangan gerak, ruang dan waktu. Rangkaian gerak yang hadir merupakan logika gerak dari satu ke gerak yang lain tanpa mengisyaratkan sesuatu maksud tertentu.

Improvisasi yang dilakukan dengan mencermati unsur-unsur yang ada dalam ngoyog bali jinjit. Dominasi kaki seperti ngoyog yaitu menggerakkan tumpuan dari satu sisi ke sisi yang lain, jinjit yaitu menjengketkan kaki, bali dipahami sebagai kembali ke sikap awal. Rangkaian gerak seperti ini terlihat seperti putaran, dari satu titik kembali ke titik, Unsur-unsur ini dicoba dengan dikembangkan ruang dan waktunya. Begitu juga kesan putaran dicobakan pada aksi tubuh yang lain seperti tangan, badan, maupun kepala. Hasil improvisasi ini menghasilkan motif-motif gerak. Selanjutnya perolehan
Jiyu Wijayanti ( NGOYOG BALI JINJIT)

gerak ini dijadikan motif awal yang selanjutnya dieksplor kembali. Tahap improvisasi ini menemukan motif-motif gerak yang sifatnya ditempat (stationery movement) dan berpindah tempa (locomotor movement).

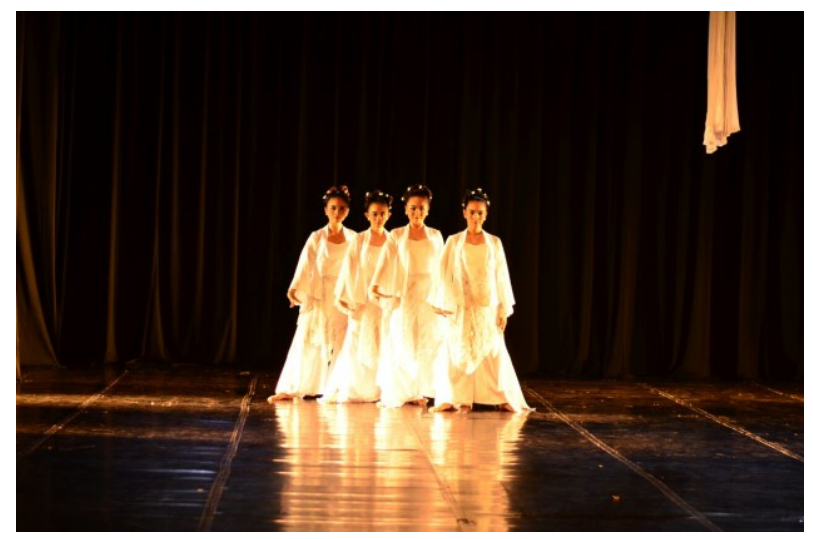

Gamb.10. Salah satu motif gerak di tempat (motif Stacato, foto: A'ari Kusuma)

\section{Metode Kontruksi 2.}

Merupakan langkah pengembangan motif, hal ini dilakukan dengan cara memanfaatkan gerak, ruang, dan waktu sebagai elemen estetis. Waktu dipahami sebagai durasi, tempo dan ritme. Durasi adalah waktu yang dibutuhkan untuk menyelesaikan suatu motif. Tempo dipahami sebagai cepat dan lambatnya suatu motif, sedangkan ritme adalah jarak antar hitungan, disini muncul ritme yang ajeg atau tidak ajeg. Sebagai gambaran, motif yang hanya berdurasi 2 hitungan bisa dilakukan sampai dengan 8 hitungan, hal ini dengan memanfaatkan aspek tempo yang diperlambat/diperpanjang, atau bisa memanfaatkan aspek ritme dengan mengatur jarak antara untuk memberikan aksentuasi dalam serangkaian gerak. Ruang 
dipahami sebagai arah, level, dimensi/volume. Mengambil contoh gerak yang sama yaitu ngoyog bali jinjit, dalam kaitan ruang ini bisa dilakukan dengan merubah arah dari kiri ke kanan atau sebaliknya, hadap depan atau belakang dstnya. Level bisa dibedakan antara medium, tinggi dan rendah. Sedangkan volume dipahami sebagai memperbesar atau memperkecil suatu gerak.

\section{Metode konstruksi 3.}

Motif menuju komposisi kelompok. Mengacu pendapat smith, bahwa pada garis besarnya aspek waktu dalam koreografi kelompok dibagi menjadi 2 yaitu rampak dan selang-seling. Masing-masing memiliki 4 variasi yaitu rampak simultan, baris depan dan belakang simultan, saling mengisi secara simultan, kontras secara simultan. Motif motif gerak yang dilakukan secara simultan ditandai/dicirii dengan waktu dan durasi yang sama dalam melakukan serangkaian gerak oleh keempat penari. Sedangkan waktu selangseling dapat divariasikan menjadi rampak berurutan, baris depan belakang berurutan, saling mengisi berurutan, kontras berurutan. Dalam kasus ini keempat penari bisa dibagi dua, masing-masing kelompok dengan 2 penari. Kelompok-kelompok ini melakukan gerak saling susul menyusul.

Ruang dalam koreografi kelompok dipahami sebagai disain-disain yang tercipta melalui gerak penari (tubuh sebagai disain visual), pola lantai yang dilalui oleh penari, disain atas yang tercipta (gerak menciptakan alur). Selain itu juga memperhatikan jarak antar penari dan arah hadap penari.

\section{Metode konstruksi 4,}

Merupakan akumulasi dari langkah sebelumnya hingga membentuk tari secara keseluruhan. Dalam tahapan ini telah terbentuk struktur koreografi dengan berbagai pertimbangan. Pertimbangan waktu melalui gerak rampak dan berturutan, sedangkan pertimbangan ruang dengan memanfaatkan titik-titik atau pusat perhatian seperti dead centre, up and down stage, left and right stage. Berdasar ruang tarinya Ngoyog Bali Jinjit terbagi dalam tujuh sesi, masing-masing adalah:

a. Sesi 1 dimulai dengan posisi level rendah di dead centre

b. Sesi 2 penari di downleft

c. Sesi 3 penari di Up left

d. Sesi 4 penari di up right

e. Sesi 5 penari di down right

f. Sesi 6 penari di down left

g. Sesi 7 penari di dead centre .

Berdasarkan geraknya masing masing sesi memiliki perbedaan, sesi 1 berisi gerak rmpak simultan dengan varisi waktu, sesi 2 berisi gerak saling mengisi, sesi 3 gerak berturutan dan rampak simultan, sesi 4 gerak stacato dan kontras simultan, sesi 5 gerak rampak dalam 
level rendah, sesi 6 gerak kontras berturutan, sesi 7 gerak saling mengisi berturutan.

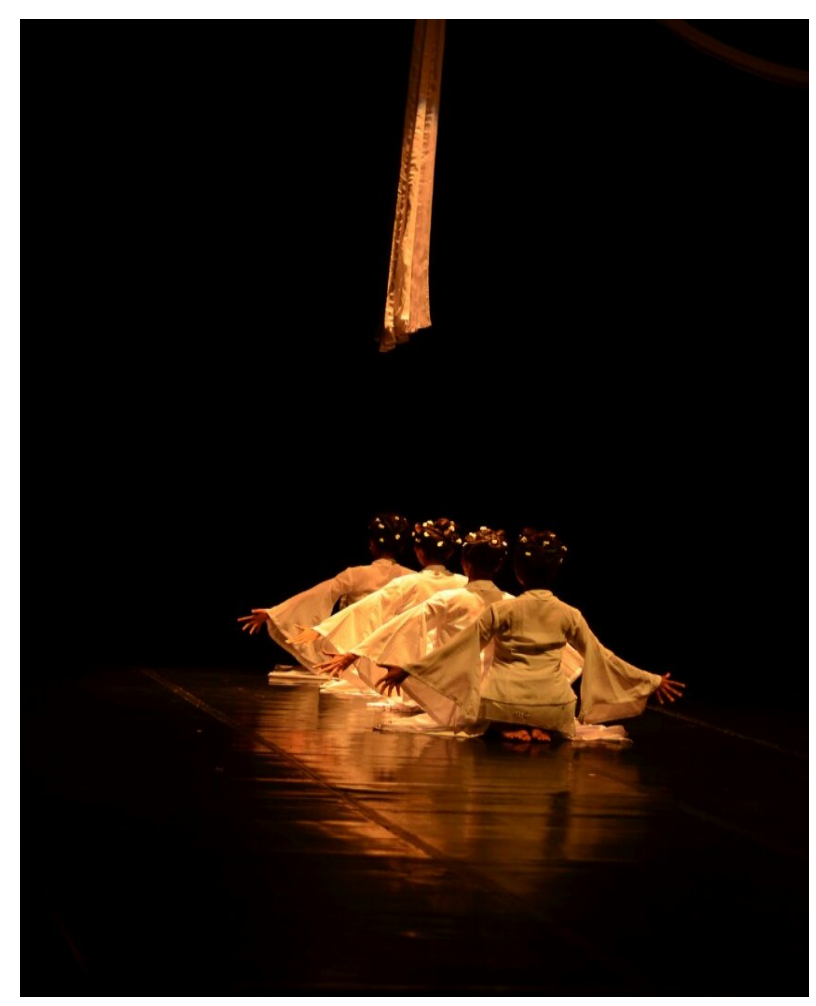

Gamb. 11. Posisi sesi 1 level rendah (Foto: Pak Jo)

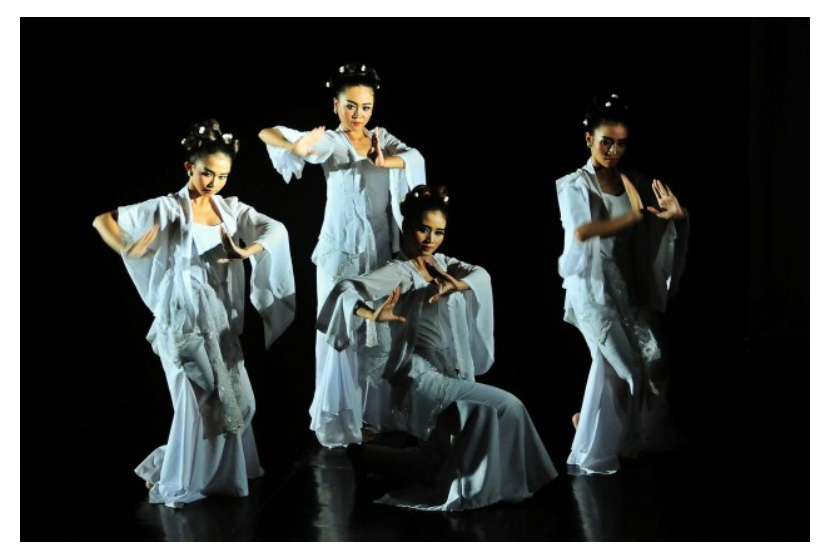

Gamb.12. Posisi sesi 2, sikap saling mengisi (down left/ Foto: Pak Jo)

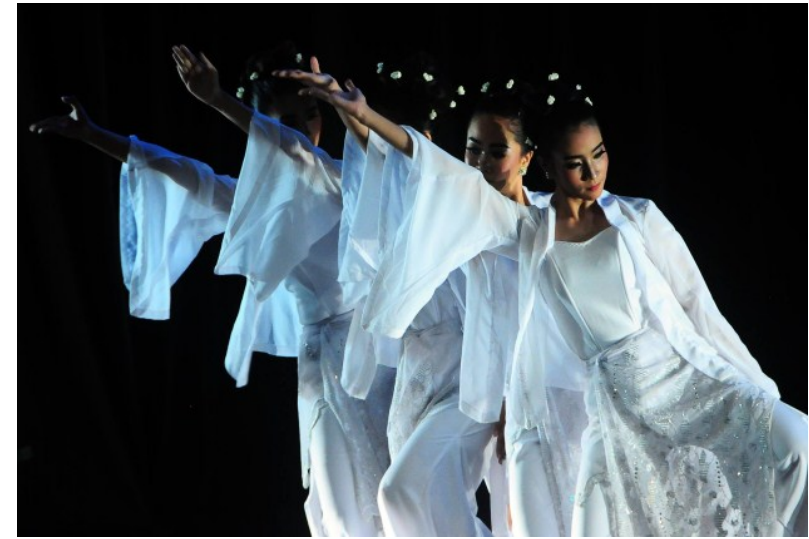

Gamb. 13. Posisi sesi 4 (up right, Foto: Pak Jo)

\section{PENUTUP}

Terwujudnya koreografi ini, memberikan pembuktian bahwa tahapantahapan yang ada mampu menuntun seseorang (pemula) untuk berhasil membuat suatu koreografi. Metode kontruksi 1 menuntun dalam menentukan rangsang tari, tipe tari dan metode penyajian. Dalam koreografi ini Ngoyog Bali Jinjit ditetapkan sebagai rangsang kinestetis, unsur-unsur yang ada dalam motif ini yaitu ngoyog, jinjit, dan leyek dipakai sebagai motif awal dalam upaya pengembangan gerak.

Tipe tari studi yang memiliki ciri adanya keterbatasan teba gerak, menuntun untuk lebih cermat dalam upaya pengayaan. Hal ini menuntun dalam bereksplorasi dan berimprovisasi Metode kontruksi 2 menetapkan motif dengan berbagai pengembangannya. Metode kontruksi 3 menemukan motif-motif dalam koreografi kelompok. Pengembangan pola waktu dalam koreografi kelompok yang secara garis besar 
dibagi dua yaitu simultan dan selang seling, mampu menciptakan ruang dengan berbagai variasinya. Metode konstruksi 4 merupakan wujud dari proses atau tahapan yang telah dilakukan, langkah ini terselesaikan dengan memanfaatkan metode konstruksi 5 yaitu dengan munculnya repetisi, variasi, transisi, sehingga mewujudkan kesatuan.

Disadari sepenuhnya bahwa koreografi ini jauh dari sempurna, namun langkah-langkah yang dilakukan dengan menerapkan metode kontruksi yang ditawarkan oleh Jacqueline Smith yang diterjemahkan oleh Ben Suharto ini mampu menjawab keraguan seorang koreografer (pemula, khususnya) dalam berkarya. Semoga karya ini bisa menjadi model dan bahan diskusi dalam kelas koreografi khususnya, dan bagi yang telah menyaksikan karya ini mohon saran dan kritik untuk karya-karya selanjutnya.

\section{DAFTAR SUMBER ACUAN}

\section{A. Sumber Tercetak}

Ben Suharto, 'Pengamatan Tari Gambyong Melalui Pendekatan Berlapis Ganda' Yogakarta

Dewan Ahli Yayasan Siswa Among Beksa, 1981, Kawruh Joged Mataram, Yogyakarta: Yayasan Siswa Among Beksa.

Fred Wibowo( editor), 1981, Mengenal Tari Klasik Gaya Yogyakarta, Yogyakarta: Liberty
Hadi, Y. Sumandiyo, 2011, Koreografi: Bentuk - Teknik - Isi, Yogyakarta: Cipta Media Bekerjasama dengan Fakultas Seni Pertunjukan ISI Yogyakarta.

2003, Aspek-Aspek Dasar Koreografi Kelompok, Yogyakarta: eLkaphi Lembaga Kajian Pendidikan dan Humaniora Indonesia

Haryono, Timbul, 2000, Peran Masyarakat Intelektual dalam Pelestarian Warisan Budaya Lokal, Pidato Ilmiah pada Dies Natalis ke-63 Fakultas Ilmu Budaya Universitas Gadjah Mada.

Hawkins, M. Alma, 2003, Bergerak Menurut Kata Hati Metode Baru Dalam Menciptakan Tari, terjemahan I Wayan Dibia, Jakarta: Ford Fondation bekerjasama dengan Masyarakat Seni Pertunjukan Indonesia.

Hersapandi, Bambang Tri, Jiyu W, 2014, Sendratari Rara Jonggrang dalam Perspektif Ekonomi Kreatif, Yogyakarta: BP ISI Yogyakarta.

Kuswarsantyo, 2014, Dialektika seni pertunjukan, Yogyakarta: Bale Seni Condroradono, Universitas Negeri Yogyakarta, Institut Seni Indonesia Yogyakarta, Sekolah Menengah Kejuruan I SMKI Kasihan.

Raditya, Michael HB, 2014, "Wayang HipHop Hibriditas Sebagai Media Konstruksi Masyarakat Urban" dalam Jantra vol. 9 no. 2, Desember 2014, jurnal Sejarah dan Budaya, $107-119$.

Rahayu Supanggah, 2002, Bothekan Karawitan I, Jakarta: Masyarakat Seni Pertunjukan Indonesia.

Smith, Jacqueline, 1985, Komposisi Tari: Petunjuk Praktis Bagi Guru(terjemahan Ben suharto), Yogyakarta: IKALASTI 
Th. Suharti, 2015, Bedhaya Semang Karaton Ngayogyakarta Hadiningrat Reaktualisasi sebuah Tari Pusaka, Yogyakarta: PT Kanisius.

Trustho, 2005, Kendang Dalam Tradisi Jawa, Surakarta: STSI Pers.

\section{B.Discografi}

Video "Nrtta Nirbhaya" karya Jiyu Wijayanti yang digelar di petilasan Ratu Boko, tahun 2005. 